\title{
POLA KOMUNIKASI TOKOH ADAT DALAM MELESTARIKAN BUDAYA TRADISIONAL SUKU SAMBORI
}

\author{
Arief Hidayatullah \\ Program Studi Ilmu Komunikasi \\ Sekolah Tinggi Ilmu Sosial dan Ilmu Politik (STISIP) Mbojo Bima NTB
}

Email: arief.stisipbima@gmail.com

\begin{abstract}
ABSTRAK
Sambori merupakan sebuah desa yang ada di wilayah Kecamatam Lambitu, Kabupaten Bima, Nusa Tenggara Barat (NTB). Desa Sambori merupakan sebuah desa yang berada didataran tinggi pengunungan Lambitu Kabupaten Bima. Kehidupan masyarakat di Desa Sambori masih tergolong sangat tradisional, dimana masyarakat masih mempertahankan nilai-nilai, norma dan aturan yang sudah sejak lama tertanam secara turun-temurun.

Masyarakat Sambori memiliki adat-istiadat yang berbeda dengan orang Bima pada umumnya. Seperti bahasa, sistem mata pencaharian, sistem kekerabatan, tradisi kesenian dan norma sosial. Masyarakat Sambori, sebagainnya masih tinggal dalam rumah adat yang di sebut "Uma Lengge". Kehidupan sosial masyarakat suku Sambori masih sangat kental dengan "nuntu ra mufaka" yang lebih di kenal dengan musyawarah. Biasanya Suku Sambori menyelesaikan setiap masalahnya dengan melakukan musyawarah untuk mendapatkan kesepatakan bersama. Tokoh adat masyarakat Sambori memiliki peran yang sangat penting dalam mewarisi serta melestarsikan berbagai budaya suku Sambori tersebut.

Pola komunikasi merupakan aktivitas komunikasi yang dilakukan secara berluang (terus-menerus) hingga menjadi tanda yang melekat pada proses komunikasi tersebut. Menurut Onong Uchjana Effendy (2010) bahwa pola komunikasi dikelompokan menajadi tiga, yakni pola komunikasi primer, sekunder dan linear. Sedangkan menurut Deddy Mulyana (2003) pola komunikasi meliputi; pola komunikasi satu arah, pola komunikasi dua arah dan pola komunikasi banyak arah.

Penelitian ini menggunakan jenis penelitian dekskriptif kualitatif. Subyek penelitian ditentukan dengan purposive sampling, yakni tokoh adat masyarakat Sambori. Teknik pengumpulan data yang digunakan adalah obsevasi, wawancara dan dokumentasi. Proses analisa data dalam penelitian ini menggunakan metode analisis data, yakni mereduksi data, display data dan penarikan kesimpulan. Uji keabsahan data yang digunakan adalah dengan triangulasi data. Data disajikan dalam bentuk deskriptif kualitatif tentang pola komunikasi tokoh ada dalam melestarikan budaya tradisional di Sambori.

Hasil penelitian menunjukan bahwa pola komunikasi tokoh adat Sambori dalam melestarikan budaya tradisional suku Sambori lebih dominan menggunakan pola komunikasi linear atau pola komunikasi dua arah. Hal tersebut terjadi karena masyarakat Sambori mempercayai tokoh adat sebagai sumber informasi sekaligus komunikator dalam berbagai hal yang berkaitan dengan kehidupan sosial masyarakat Sambori.
\end{abstract}

Kata Kunci: Komunikasi, Tokoh Adat, Budaya Trasional, Suku Sambori. 


\section{PENDAHULUAN}

Sambori merupakan sebuah desa yang ada di wilayah Kecamatam Lambitu, Kabupaten Bima, Nusa Tenggara Barat (NTB). Secara geografis Desa Sambori berada didataran tinggi pengunungan Lambitu yang berada dibagian selatan dari pusat pemerintahan Kabupaten Bima. Jarak Desa Sambori dengan pusat pemerintahan Kabupaten Bima sekitar $60 \mathrm{~km}$. Secara demografis, Desa Sambori didiami oleh sekitar 800 jiwa, dengan mata pencaharian utama adalah sebagai petani, sebagian kecil sebagai guru dan aparutur pemerintah.

Menilik dari sejarah, keberadaan masyarakat (orang) di wilayah Sambori akibat dari pergolakan yang ada pada pusat pemerintahan Kerajaan Bima pada masa lampau. Pada masa itu, ada sebagian rakyat Bima yang keberatan dengan kebijakan kerja sama antara Kerajaan Bima dengan penjajah Belanda. Rakyat yang menolak tersebut memilih menjauh dari pusat pemerintahan Kerajaan Bima. Sebagian dari rakyat tersebut menempati gugusan pegunungan Lambitu yang berada dibagian selatan dari pusat kerjaaan Bima dan pegunungan Soromandi yang ada di sebelah barat dari pusat kerjaaan Bima.

Secara historis orang Bima pada awalnya disebut dou mbojo (orang Mbojo). Karena pengaruh kerjaan Bima, maka istilah Mbojo diganti dengan Bima, sesuai dengan nama daerah atau kerajaan Bima. Dari sejarah tersebut, maka masyarakat dibagi menjadi dua kelompok masyarakat, yaitu masyarakat asli yang disebut dengan dou donggo dan masyarakat hasil pembauran budaya asli dengan pendatang yang disebut dengan dou mbojo atau orang Bima.

Dou donggo merupakan sebutan yang diberikan kepada dou mbojo yang tinggal dipegunungan. Dou donggo menempati dua wilayah pegunungan dari empat wilayah pegunungan yang ada di wilayah Bima, yakni pengunungan bagian selatan dan barat. Dou donggo yang menempati wilayah pegunungan selatan disebut dou donggo ele, sedangkan dou donggo yang menempati wilayah pegunungan barat disebut dou donggo ipa. 
Dalam perkembangan masyarakat dan penataan adminsitrasi pemerintahan, maka sebutan dou donggo ele dan dou donggo ipa memudar bahkan sampai menghilang pada masyarakat Bima. Sebutan untuk masyarakat tersebut tergantikan dengan nama administrtatif yang ditetapkan oleh pemerintah dalam bentuk nama pemerintahan desa atau kecamatan. Dou donggo ele lebih dikenal dengan dou sambori (orang Sambori) karena daerah tempat tinggal dou donggo ele tersebut dinamakan Desa Sambori. Sedangkan dou donggo ipa dikenal dengan dou donggo (orang Donggo) karena daerah tempat tinggal dou donggo ipa tersebut dinamakan Kecamatan Donggo.

Kehidupan masyarakat di Desa Sambori masih tergolong sangat tradisional. Masyarakat Sambori masih mempertahankan nilai-nilai, norma dan aturan yang sudah sejak lama tertanam secara turun-temurun. Masyarakat Sambori memiliki adat istiadat yang berbeda dengan orang Bima. Hal tersebut bisa dilihat dari tempat tinggal, bahasa, tradisi kesenian, system mata pencaharian, kekerabatan dan pengobatan. Selain hal tersebut, keberadaan tokoh adat atau kepala suku menjadi ciri masih kentalnya nilai-nilai tradisional dalam masyarakat Sambori.

Pada masa awal keberadaan masyarakat Sambori, mereka membangun rumah tinggal dengan desain yang cukup unik. Rumah dibangun dalam tiga tingkat, dengan ketinggian antara 5-7 meter dan luas 3x3 meter, yang disebut dengan uma lengge (rumah tinggi). Rumah tersebut pada bagian paling bawah sebagai tempat hewan ternak, pada bagian kedua sebagai ruang terbuka yang berfungsi untuk menerima kerabat, pada bagian paling atas sebagai tempat tidur, aktivitas memasak dan untuk menyimpan bahan pangan.

Sebagai ciri suatu masyarakat, masyarakat Sambori memiliki kebudayaan tersendiri sebagai identitas masyarakatnya. Ciri budaya tersebut seperti bahasa, pakian adat, kesenian, dan pengobatan tradisonal. Dalam penggunaan bahasa, masyarakat Sambori memiliki bahasa yang berbeda dengan masyarakat Bima umumnya. Masyarakat Sambori masih menggunakan 
bahasa asli dou mbojo yang belum terkontaminasi dengan bahasa pendatang atau bahasa Indonesia. Meski demikian, kalau berinteraksi dengan masyarakat luar, masyarakat Sambori menggunana bahasa Bima atau bahasa Indonesia sebagai alat komunikasi.

Pakaian adat masyarakat Sambori berbeda dengan pakaian adat suku Bima dan Dompu pada umumnya. Pakaian adat laki-laki dewasa disebut dengan sambolo (ikat kepala) yang terbuat dari kain kapas tenunan dengan hiasan kotak-kotak berwarna hitam atau putih. Dipadu dengan baju mbolo wo,o yaitu baju tampa kerah yang terbuat dari kain katun diwarnai hitam atau putih. Masyarakat Sambori memakai sarung yang disebut tembe me,e (sarung hitam), dengan cara dililit pada bagian perut. Kemudian mereka memakai aksesoris weri atau bala (kain ikat pinggang) yang diselempangkan melingkar pada bagian perut sampai di atas paha, yang berfungsi menguatkan lilit sarung. Mereka juga menggunakan cincin yang terbuat dari bahan besi putih atau perak yang diberi batuk akik.

Sedangkan para perempuan dewasa memakai baju poro me,e, yaitu pakaian adat yang terbuat dari kain katun dengan bentuk menyerupai baju poro pada, pakaian masyarakat Bima pada umumnya. Sementara bawahanya memakai tembe me,e (sarung hitam) yang dibuat agak panjang karna cara memakainya yaitu dengan cara dimasukan secara lurus melalui kepala dengan kaki. Kemudian dibiarkan lepas sampai dibetis, sekedar pelengkap mereka menggunakan kababu (selendang) yang diselempangkan pada bahu. Untuk rambut ditata dengan membuat semacam ikatan dibentuk meninggi di atas kepala yang disebut $s a m u, u t u, u$ (ikat kepala model tegak).

Budaya tradisional yang ada pada masyarakat Sambori masih dipercayai dan dipraktikan oleh masyarakat sebagai falsafah hidup bagi masyarakat Sambori hingga saat ini. Budaya tradisional yang sudah melekat tersebut secara turun-temurun dipraktikan masyarakat Sambori ditengah terpaan budaya luar yang sangat masif. Keteguhan masyarakat Sambori dalam meletarikan budaya, menjadi hal yang menarik untuk dipaparkan kepada khalayak 
luas. Peran tokoh adat menjadi kunci dalam melestarikan budaya tradisional masyarakat Sambori. Dalam konteks komunikasi, tokoh adat berperan sebagai komunikator dalam melestarikan budaya tradisional masyarakat Sambori.

\section{TINJAUAN PUSTAKA}

\section{Konsep Komunikasi dan Pola Komunikasi}

Harold Laswell mengatakan cara yang baik untuk menggambarkan komunikasi adalah dengan menjawab pertanyaan-pertanyaan berikut "who says what in which chennel to whom with what effect?" (siapa mengatakan apa dengan saluran apa kepada siapa dengan pengaruh bagaimana). Dari konsep Laswell tersebut, setidaknya ada lima unsur atau komponen yang harus ada dalam aktivitas komunikasi, yakni komunikator (orang yang menyampaikan pesan), pesan (pernyataan yang disampaikan oleh komunikator), komunikan (orang yang menerima pesan), media (sarana yang mendukung pesan apabila komunikan jauh tempatnya atau banyak jumlahnya), dan efek (dampak sebagai pengaruh dari pesan).

Proses komunikasi merupakan rangkaian dari aktivitas menyampaikan pesan sehingga menghasilkan feedback dari penerima pesan. Dari proses komunikasi tersebut akan menimbulkan pola, model, bentuk dan juga bagian-bagian kecil yang berkaitan erat dengan proses komunikasi. Pola merupakan suatu konsep untuk menjelaskan tentang aktivitas yang dilakukan secara terus menerus sehingga menjadi ciri khas dari sesuatu. Dalam konteks komunikasi, pola komunikasi merupakan konsep untuk menjelaskan tentang proses komunikasi yang dilakukan secara terus-menerus sehingga menjadi kebiasaan, ciri khas atau budaya dari suatu masyarakat tertentu.

Pola komunikasi dibagi dalam tiga kategori, yakni pola komunikasi primer, pola komunikasi sekunder, pola komunikasi linear, dan pola komunikasi sirkular (Effendy, 2005). Pertama, pola komunikasi primer; pola ini merupakan suatu proses penyampaian pikiran oleh 
komunikator kepada komunikan dengan menggunakan suatu simbol atau lambang sebagai media atau saluran. Simbol atau lambang tersebut dalam bentuk verbal (bahasa) dan non verbal (gerakan tubuh). Kedua, pola komunikasi sekunder; pola komunikasi ini merupakan proses penyampaian pesan oleh komunikator kepada komunikan dengan menggunakan alat atau sarana sebagai media kedua setelah memakai simbol atau lambang sebagai media media pertama. Pola komunikasi ini menggunakan media atau alat komunikasi sebagai sarana untuk meneruskan pesan kepada komunikan yang lebih luas.

Ketiga, pola komunikasi linear. Linear di sini mengandung makna lurus yang berarti perjalanan dari satu titik ke titik lain secara lurus, yang berarti penyampaian pesan oleh komunikator kepada komunikan sebagai titik terminal. Jadi dalam proses komunikasi ini biasanya terjadi dalam komunikasi tatap muka (face to face), tetapi juga ada kalanya komunikasi bermedia. Dalam proses komunikasi ini pesan yang disampaikan akan efektif apabila ada perencanaan sebelum melaksanakan komunikasi. Keempat, Pola komunikasi sirkular. Dalam proses komunikasi sirkular itu terjadinya feedback atau umpan balik, yaitu terjadinya arus dari komunikan ke komunikator, sebagai penentu utama keberhasilan komunikasi. Dalam pola komunikasi yang seperti ini proses komunikasi berjalan terus yaitu adaya umpan balik antara komunikator dan komunikan.

Selain pola komunikasi yang dipaparkan di atas, Deddy Mulyana (2003) mengemukakan konsep lain dari pola komunikasi. Pertama, komunikasi satu arah (one way communication); suatu proses penyampaian pesan yang hanya datang dari komunikator tanpa ada umpan balik atau tanggapan dari komunikan baik secara langsung (tatap muka) ataupun melalui media. Kedua, komunikasi dua arah (two way communication); pandangan ini menyetarakan komunikasi dengan suatu proses sebab akibat atau reaksi aksi yang arahnya bergantian. Komunikasi dua arah dipandang lebih dinamis dari pada arah komunikasi satu arah. Salah satu unsur komunikasi yang ditambahkan dalam pola komunikasi dua arah 
adalah feedback atau umpan balik, yakni apa yang disampaikan komunikan kepada komunikator, yang sekaligus digunakan sumber sebagai petunjuk apakah pesan yang disampaikan dapat dimengerti atau dapat diterima oleh komunikan. Ketiga, komunikasi banyak arah (multy way communication); komunikasi banyak arah disebut komunikasi sebagai transaksi yaitu suatu proses personal karena pesan atau makna pemahaman yang kita peroleh pada dasarnya bersifat pribadi. Komunikasi ini bersifat dinamis, pandangan ini yang di sebut komunikasi sebagai transaksi, yang lebih sesuai untuk komunikasi tatap muka yang memungkinkan pesan atau respon verbal dan nonverbal bisa diketahui secara langsung. Komunikasi yang berlangsung multi arah diantara penerima menuju ke semua fokus atau minat yang di pahami bersama.

\section{Konsep Masyarakat dan Budaya Tradisional}

Masyarakat adalah sekelompok individu yang memiliki kepentingan bersama dan memiliki budaya serta lembaga yang khas. Masyarakat juga bisa dipahami sebagai sekelompok orang yang terorganisasi karena memiliki tujuan bersama. Masyarakat menurut Max Weber adalah sebagai suatu struktur atau aksi yang pada pokoknya ditentukan oleh harapan dan nilai-nilai yang dominan pada warganya. Sedangkan menurut sosiolog Emile Durkheim, bahwa masyarakat adalah suatu kenyataan objektif individu-individu yang merupakan anggota-anggotanya (Ritzer, 2004).

Masyarakat tradisional adalah masyarakat yang kehidupannya masih banyak dikuasai oleh adat istiadat lama. Masyarakat tradisional dalam melangsungkan kehidupannya berdasarkan pada cara-cara atau kebiasaan-kebiasaan lama yang masih diwarisi dari nenek moyangnya. Kehidupan mereka belum terlalu dipengaruhi oleh perubahan-perubahan yang berasal dari luar lingkungan sosialnya. 
Kebudayaan masyarakat tradisional merupakan hasil adaptasi terhadap lingkungan alam dan sosial sekitarnya tanpa menerima pengaruh luar. Jadi, kebudayaan masyarakat tradisional tidak mengalami perubahan mendasar. Karena peranan adat-istiadat sangat kuat menguasai kehidupan mereka.

Masyarakat tradisional hidup di daerah pedesaan yang secara geografis terletak di pedalaman yang jauh dari keramaian kota. Masyarakat ini dapat juga disebut masyarakat pedesaan atau masyarakat desa. Masyarakat desa adalah sekelompok orang yang hidup bersama, bekerja sama, dan berhubungan erat secara tahan lama, dengan sifat-sifat yang hampir seragam.

\section{METODE PENELITIAN}

Penelitian ini menggunakan jenis penelitian dekskriptif kualitatif, yakni penelitian yang bermaksud untuk memahami fenomena tentang apa yang dialami oleh subjek penelitian misalnya perilaku, persepsi, motivasi, tindakan, dan lain-lain. Penelitian akan dilakukan di Desa Sambori Dusun Lengge Kecematan Lambitu, Kabupaten Bima. Pemilihan lokasi ini karena melihat betapa pentingnya pelestarian sebuah budaya tradisional, khususnya di Sambori yang merupakan sebuah desa yang masih sangat kental akan budaya tradisionalnya. Dalam penelitian penulis menentukan subjek atau informan penelitian sebagai kunci informasi yaitu: Ketua adat suku Sambori, Alwi (69) yang telah menjadi ketua suku selama lebih dari sepuluh tahun sebagai sumber informasi utama.

Teknik pengumpulan data yang digunakan dalam penelitian ini adalah menggunakan obsevasi, wawancara dan dokumentasi. Proses analisa data dalam penelitian ini menggunakan metode analisis data Miles dan Huberman, yakni mereduksi data, display data dan penarikan kesimpulan. Uji keabsahan data yang digunakan dalam penelitian ini adalah dengan triangulasi data yakni menggunakan berbagai sumber data seperti dokumen, arsip, hasil 
wawancara, hasil observasi atau juga dengan mewawancarai lebih dari satu subjek yang dianggap memiliki sudut pandang yang berbeda. Data disajikan dalam bentuk deskriptif kualitatif, yakni menyajikan data dalam bentuk uraian bahasa tentang pola komunikasi tokoh ada dalam melestarikan budaya lokal di Sambori.

\section{HASIL PENELITIAN}

Dari hasil observasi dan wawancara dengan informan penelitian, masyarakat Sambori memiliki berbagai kebudayaan yang masih melekat dalam kehidupan sosial masyarakat. Kebudayaan tersebut menjadi ciri khas masyarakat Sambori yang membedakan dengan masyarakat Bima pada umumnya.

1. Budaya Paresa wa Nggahi (musyawarah); Masyarakat Sambori masih memegang teguh prinsip musyawarah dalam setiap menggambil keputusan untuk semua kegiatan masyarakat. Baik itu musyawarah untuk merencanakan kegiatan atau musyawarah untuk menyelesaikan masalah yang ada. Nuntu ra nggahi atau musyawarah dipimpin oleh tokoh adat atau pejabat pemerintah.

2. Budaya Karawi Sama (Gotong Royong); Gotong royong menjadi ciri khas masyarakat tradisional. Begitu juga dengan masyarakat Sambori. Masyarakat Sambori selalu menyelesaikan pekerjaan yang berkaitan dengan kemasyarakatan dilakukan secara bersama-sama, seperti membangun rumah, bercocok tanam dan pernikahan.

3. Budaya Maleko wa Cola (Jual dan Beli); Dalam hal transaksi jual-beli, masyarakat Sambori masih menggunakan sistem barter ketika melakukan transaksi jual-beli sesama masyarakat Sambori. Hal tersebut terjadi karena hubungan kekerabatan yang sangat erat dalam masyarakat Sambori. Masyarakat Sambori merupakan satu keluarga besar yang mendiami wilayah tersebut. 
4. Budaya Mabadu Pare (Tumbuk Padi); meskipun alat pengiling padi sudah ada disekitra Desa Sambori, namun masyarakat Sambori masih menggunakan alat tradisional untuk menumbuk padi. Hal tersebut dilakukan karena hasil beras yang ditumbuk dengan alat tradisional lebih lezat, higienis dan beraroma alami. Masyarakat Sambori menumbuk padi secara tradisional dengan menggunakan "Nocu dan Aru” yaitu alat yang digunakan untuk menumbuk padi.

5. Budaya Nggahi Sambori (Bahasa Sambori); Sampai saat ini, masyarakat Sambori masih menggunakan bahasanya sendiri. Bahasa Sambori berbeda dengan bahasa Bima pada umumnya. Berikut perbandingan bahasa Sambori dengan bahasa Bima dalam table 1.

Tabel 1. Perbandingan Bahasa Sambori, Bahasa Bima

\begin{tabular}{|c|l|l|l|}
\hline No. & \multicolumn{1}{|c|}{ Bahasa Indonesia } & \multicolumn{1}{|c|}{ Bahasa Bima } & \multicolumn{1}{c|}{ Bahasa Sambori } \\
\hline 1 & Siapa & Cou & Se \\
\hline 2 & Saya & Nahu & Rae \\
\hline 3 & Kamu & Nggomi & Oe \\
\hline 4 & Kaki & Edi & Langge \\
\hline 5 & Tangan & Rima & Lima \\
\hline 6 & Kepala & Tuta & Po'o \\
\hline 7 & Makan & Ngaha & Aparawi \\
\hline 8 & Nasi & Oha & Manis \\
\hline 9 & Teman & Lenga & Inge \\
\hline 10 & Lari & Rai & Ayam \\
\hline
\end{tabular}

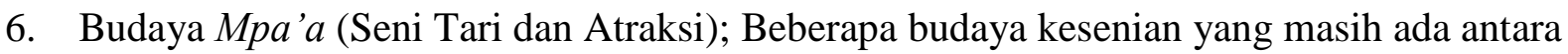
lain adalah budaya seni tari dan atraksi. Beberapa seni tari dan atraksi yang masih bertahan antara lain seperti "Mpa,a Manca, Lanca, Mpa,a buja, Mpa,a Genda, dan Mpa,a Sila”. Mpa,a Manca merupakan tarian tradisional dimana dua orang pemuda memerankan dirinya sebagai perajurit perang yang saling bertarung. Mpa'a Lanca merupakan permainan adu betis biasanya diperankan oleh dua orang pemuda yang kemudian mengadu kekuatan fisik mereka dengan mengangkat salah satu kakinya dan menggunakan kakinya yang lain untuk menyerang dan menjatuhkan lawannya. Mpa,a 
Buja merupakan salah satu seni tari dan atraksi yang dimainkan dua orang pemuda yang menggunakan pedang kayu panjang seukuran satu meter, dan berbusana pakaian adat suku Sambori lengkap yang bertujuan menguji kekuatan kedua pemaian. Biasanya seni tari dan atraksi yang satu ini dimainkan saat acara pernikahan. Mpa,a Genda, seni yang satu ini dapat dikategorikan ke dalam dua jenis seni, yang pertama seni tari dan atraksi dan kedua seni musik, hal ini dikarnakan proses saat berlangsung kedua hal tersebut di padukan, dimana terdapat beberapa orang pemain musik yang bertugas memainkan gendang sementara beberapa yang lain melakukan tarian atraksi seperti pencat silat sesuai iringan musik yang dimainkan. Biasanya Mpa,a Genda dimainkan pada acaraacara hajatan seperti pernikahan, khatam dan sunatan. Mpa,a Sila merupakan salah satu tarian tradisional dari sekian banyak tarian dan atraksi tradisional suku Sambori, yang diperankan oleh dua orang pemuda. Kedua pemuda tersebut saling mengadu kekuatannya dengan menggunakan pedang besi yang diiringi musik menggunakan salah satu instrumen musik tradisional yang bernama "Gonda no silu”. Biasanya Mpa, a Sila dimainkan pada acara sunatan dan khatam.

7. Budaya Lawa (Nyanyian); budaya nyanyian tradisional yang masih bertahan hingga saat ini dalam masyarakat Sambori adalah "Baleleha". Balelaha dinyanyikan saat acara pernikahan, untuk menyambut tamu-tamu penting berkunjung ke desa, seperti saat kedatangan bupati. Balelaha merupakan seni musik vokal tertua. Seni Vokal ini berisikan doa dan pengharapan agar tanah dan negri, keluarga dan masyarakat senantiasa mendapat perlindungan dari sang Khaliq dan dijauhkan dari bencana. Syair belaleha berisi pertuah, nasehat, pantun dan pujian serta harapan kepada yang maha kuasa. Sesuai fungsinya baleleha dibagi menjadi dua jenis, yaitu balelaha randa dan baleleha ranca. Baleleha Randa dihajadkan untuk penobatan seseorang dalam suatu upacara adat dan pada masa pra Islam untuk mempersembahkan sesajian, tetapi setelah Islam masuk ritual 
tersebut tidak dilaksanakan lagi. Sedangkan beleleha ranca digelar untuk hiburan biasa. Balelaha yang saat ini masih bertahan adalah beleleha ranca.

8. Budaya Nana (Kerajinan Anyaman); Beberapa hasil kerajinan yang dapat di buat dengan daun rotan antara lain seperti "Saduku, Kula, dan kaleru” Sementara beberapa kerajinan yang dapat di buat dengan bahan daun pandan antara lain seperti, "Dipi" atau tikar, dan "Waku" atau Payung tradisional suku Sambori, sedangkan "Sarau” atau Caping, "Doku” atau Nyiru dan "Wonca" atau Bakul adalah kerajinan yang dapat dibuat dengan menggunakan bambu. Kerajinan lainnya yang dapat di buat menggunakan batok kepala antara lain seperti, "Cedo" atau Sendok tradisional dari batok kepala dan "Sewa tua" atau Piring yang digunakan untuk meminum obat.

9. Budaya Kangguhu (Bercocok Tanam); Sebelum memulai bercocok tanam masyarakat suku Sambori biasanya melakukan musyawarah terlebih dahulu untuk menentukan waktu musim tanam di mulai, biasanya masyarakat suku Sambori memulai musim tanamnya sesuai kesepakatan bersama yang diperoleh dari hasil musyawarah, setelah kesepakatan tersebut didapatkan masyarakat suku Sambori melakukan ritual atau do,a terlebih dahulu yang dikenal dengan sebutan "Do, a selama dana". Selanjutnya tahap kedua adalah doa saat musim tanam sedang berlangsung yaitu "do, a raho taho selama kanggihi karawi”. Ritual ini dimaksudkan untuk meminta keberkahan tuhan selama musim tanam sedang berlangsung. Biasanya ritual ini dilakukan satu bulan setelah "Doa selama dana”, Tahap terakhir adalah melakukan ritual "Do, a syukur”, yang berlangsung saat masyarakat suku Sambori mulai melakukan musim panen. Doa Syukur biasanya dilaksanakan pada ladang milik salah satu masyarakat suku Sambori. Hal ini bertujuan untuk meminta keselamatan dan rahmat tuhan saat masyarakat Sambori memulai musim tanam. 
10. Budaya Nika ra Neku (Pernikahan); Beberapa proses dari tradisi pernikahanya antara lain, tahap yang pertama dilakukan adalah musyawah, tentu saja hal ini harus dilakukan karna Suku Sambori masih sangat kental dengan "Mbolo ra Mufaka". Setelah menetapkan tanggal pernikahan dan membuat kesepakatan lainnya pada tahap sebelumnya, maka tahap selanjutnya adalah mengumpulkan berbagai peralatan dapur dari berbagai anggota suku yang akan digunakan dalam acara pernikahan. Dalam proses pernikahannnya, masyarakat Suku Sambori tidak menggadakan pesta pernikahan seperti yang dilakukan masyarakat Bima, melainkan hanya melakukan ijab kabul, sebagai tanda syah menjadi suami istri menurut Islam karena pada dasarnya seluruh masyarakat suku Sambori memeluk agama Islam. Pada hari yang sama saat proses ijab kabul berlangsung, pihak keluarga yang berhajat akan melakukan acara doa sebagai bentuk rasa syukur. Setelah menikah, pengantin wanita harus membawa kayu bakar dan air untuk keluarga suaminya. Hal ini dilakukan sebagai bentuk syahnya menjadi menantu. Dalam hal ini si wanita belum bisa memasuki rumah mertuanya. Pengantin wanita harus pulang kembali ke rumahnya setelah melakukan tugasnya. Setelah sampai di rumah mertuanya yang akan menjadi tempat tinggalnya yang baru pengantin wanita akan disirami dengan air tepat pada tangga rumah. Hal ini dilakukan agar si wanita menyadari perubahan identitasnya serta siap mengambil tanggung jawab sebagai seorang ibu rumah tangga. Proses selanjutnya adalah penerimaan sebagai anggota keluarga, dimana mertua harus mencuci kaki menantunya. Hal ini dilakukan agar mertua menyadari bahwa menantunya sudah menjadi tanggung jawabnya.

11. Budaya Tama Qaro'a (Khatam Al-Quran); Tradisi Upacara khatam suku Sambori dibagi ke dalam dua tahap, sebelum hari pelaksanaan khatam dan hari saat khatam dilaksanakan. Dua hari sebelum acara khatam berlangsung, paginya anak yang melakukan hatam Al-quraan harus membawa beras, pinang, ayam, daun rotan, tembakau, 
daun sirih, kapur padat, dan kain kafan pada ibu angkatnya, jika Dia tidak memiliki ibu angkat maka Dia harus membawa pada neneknya dan menginap di rumah tersebut. Pada pagi harinya lagi harus kembali ke rumah ibu kandungnya bersama keluarga dan sanak saudara dari ibu angkata atau neneknya. Anak diwajibkan membawa kembali barang yang di bawa pada ibu angkatnya kembali ke rumah ibu kandungnya. Di rumah ibu kandungnya, tempat acara khatam diselenggarakan beberapa ibu-ibu telah menunggu bersama keluarga anak. Saat anak sampai, beberapa ibu-ibu tersebut langsung mencegat dan menutup jalan kemudian melakukan caci maki kepada anak berserta beberapa orang yang telah mengantarnya. Jika si anak berserta orang yang mengantarnya bisa melewati beberapa ibu-ibu yang melakukan caci maki maka si anak dan beberapa orang yang mengantarnya bisa masuk ke rumah keluarga kandung si anak dengan melewati beberapa anak tangga. Pada malamnya, anak yang melakukan Khatam wajib pergi ke rumah guru ngajinya dengan membawa oha mina (nasi kuning/santan), kalo jawa (pisang jawa), uta janga (daging ayam), lingga (bantal), dipi (tikar), sajadah (sajadah), qaro,a (al-quran) dan pengaha (jajanan) sebagai rasa terimakasih atas jasa sang guru yang telah mengajarkan Ngaji untuk anak yang melakukan Khatam. Saat berkunjung ke rumah guru ngajinya, si anak datang bersama ibu, ayah dan kakeknya yang diantar dengan salawat .

12. Budaya Lo’i (Pengobatan); Pengobatan tradisional bukan menjadi alternatif namun menjadi pilihan utama dalam mengobati berbagai penyakit yang di derita masyarakat suku Sambori. Masyarakat Sambori memiliki tiga jenis teknik pengobatan antara lain, teknik racikan ramuan bahan herbal, teknik pijat atau urut dan air do'a. Teknik Pengobatan menggunakan racikan ramuan herbal merupakan media pengobatan menggunakan tanaman dengan kandungan bahan-bahan alami sebagai bahan bakunya, biasanya bahan-bahan yang dimanfaatkan adalah, kunyit, bawang putih, daun sirih, bawang merah, kelopak kayu, dll. Tenik pengobatan pijat dan urut yang merupakan 
metode penyembuhan kesehatan tradisional dengan cara memberikan penekanan kepada tubuh, baik secara terstruktur, tidak terstruktur, menetap atau berpindah tempat dengan memberikan tekanan, gerakan, atau getaran. Biasanya masyarakat Sambori melakukan teknik pemijatan dengan dibarengi racikan ramuan herbal ataupun air putih yang telah di bacakan doa oleh seorang tabib. Teknik pengobatan lainnya adalah air doa. Dimana seseorang membacakan doa pada air putih yang kemudian di minum oleh si penderita. Biasanya beberapa penyakit yang diobati menggunakan teknik air doa adalah, demam, panas, cacar, bisulan, kerasukan, dan lainnya.

\section{PEMBAHASAN}

Kehiduapan sosial masyarakat Sambori di era milinela ini, telah dirasuki budaya dan teknologi modern seperti halnya masyarakat pada umumnya. Meski demikian masyarakat Sambori masih dalam balutan budaya tradisionalnya. Nilai-nilai budaya tradisional yang selalu menaungi masyarakat Sambori sebagian masih dipercaya dan dilaksanakan oleh masyarakat Sambori.

Keberlangsungan nilai-nilai budaya tradisional pada masyarakat Sambori merupakan suatu hasil usaha bersama masyarakat untuk tetap mempertahankan kebudayaannya. Semua elemen masyarakat selalu mengikuti rangkaian kebudayaan tersebut secara turun-temurun, sehingga setiap generasi masih bisa menikmati kebudayaan yang menjadi identitas masyarakat Sambori. Keberlangsungan kebudayaan masyarakat Sambori tersebut tidak terlepas dari peran tokoh adat masyarakat Sambori.

Tokoh adat merupakan pemuka masyarakat yang secara turun-temurun dipercayai sebagai orang yang tertua, orang yang lebih tahu, orang yang keturunan langsung dari pendiri kampong dan orang yang dipercayai memiliki kekuatan supranatural. Tokoh adat memiliki 
peran yang sangat penting dalam kehidupan sosial masyarakat Sambori. Tokoh adat adalah segalanya. Tokoh adat merupakan "nyawah" bagi masyarakat Sambori.

Tokoh adat masyarakat Sambori saat ini adalah Bapak Alwi (70). Dalam keseharian masyarakat Sambori, tokoh adat tersebut dipanggil dengan sebutan oтри (kakek). Ompu Alwi merupakan generasi ketiga dari pendiri kampung Sambori. Keberadaan ompu Alwi menjadi sentra informasi, keputusan dan keteladanan untuk masyarakat Sambori. Setiap aktivitas sosial masyarakat Sambori rujukannya adalah ompu Alwi, demikian juga dalam hal kebudayaan. Ompu Alwi memiliki peran yang sangat vital dalam pelestarian kebudayaan masyarakat Sambori. Ompu Alwi menjadi sumber utama dalam memahami nilai-nilai kebudayaan dalam masyarakat Sambori.

Dalam konteks komunikasi, keberadaan Ompu Alwi merupakan sebagai sumber informasi utama. Ompu Alwi merupakan komunikator dalam setiap aktivitas komunikasi masyarakat Sambori. Sebagai seorang komunikator, Ompu Alwi selalu menjalin komunikasi dengan seluruh elemen masyarakat tentang berbagai hal. Ompu Alwi juga menerima masukan atau tanggapan dari komunikan dalam setiap aktivitas komunikasnya.

Pola komunikasi yang dilakukan Ompu Alwi kalau dilihat dari perspekti pola komunikasi, maka pola komunikasi yang dilakukan Ompu Alwi adalah pola komunikasi linear atau pola komunikasi dua arah (two ways communication). Ompu Alwi selalu menjalin komunikasi dua arah dengan seluruh elemen masyarakat Sambori. Ompu Alwi berperan sebagai komunikator sekaligus sebagai komunikan.

Menurut Ompu Alwi, hal tersebut dilakukan untuk menarik perhatian dari masyarakat. Sebap, dengan mendengarkan masukan dari masyarakat, maka masyarakat merasa dihargai oleh pimpinan dalam lingkunganya. Dengan demikian, setiap aktivitas masyarakat bisa diselelsaikan secara bersama sesuai dengan peran dan fungsinya masing-masing. Demikian juga dalam hal pelestarian kebudayaan masyarakat Sambori. 
"Ndaiku ntuwu nuntu labo dou aka rasa ro dana Sambori ake. Ndaiku karongga au ndei eli ra ngoa bu dou ma tua ntoina. Ndaiku karonggampa. Ndaiku ka kade'e ngahi dou mamboto rau. (Saya selalu mejalin komunikasi dengan semua masyarakat. Saya sampaikan apa yang disampaikan oleh orang tua terdahulu. Saya hanya menyampaikan. Selain menyampaikan, saya juga mendengarkan masukan dari masyarakat luas". (hasil wawancara 25 Juni 2018).

Untuk mendukung proses komunikasi dua arah tersebut, Ompu Alwi juga menggunakan alat komunikasi sebagai media untuk meneruskan pesan kepada seluruh masyarakat Sambori. Alat komunikasi yang digunakan adalah alat komunikasi berupa kentongan dan toa atau speaker dari masjid. Selain alat komunikasi, Ompu Alwi juga menugaskan sesorang untuk meneruskan pesan dari Ompu Alwi kepada masyarakat. Hal ini dilakukan untuk menjangkau masyarakat Sambori yang berada jauh dari pusat desa, seperti yang tinggal di ladang atau di sawah.

\section{KESIMPULAN}

Dalam melestarikan kebudayaan tradisional, tokoh adat masyarakat Sambori Ompu Alwi selalu menggunakan pola komunikasi dua arah atau komunikasi linear. Pola komunikasi ini lebih efektif dalam usaha melestarikan kebudayaan tradisional masyarakat Sambori ditengahtengah terpaan budaya modern pada era milineal ini.

\section{DAFTAR PUSTAKA}

Effendy. Onong Uchjana, (2005). Dinamika Komunikasi. Bandung: Remaja Rosdakarya. Mulyana, Deddy, (2003). Ilmu Komunikasi Suatu Pengantar. Bandung: Rosda Karya. Fiske, John, (2012). Pengantar Ilmu Komunikasi. Jakarta: PT. Raja Grafindo Persada.

Ritzer, George dan Douglas J. Goodman, (2004). Teori Sosiologi Modern. Jakarta: Prenada Media. 